\title{
Small business owners and health
}

\author{
Olivier Torrès • Roy Thurik
}

Accepted: 26 March 2018 / Published online: 19 May 2018

(C) The Author(s) 2018

\begin{abstract}
The present article identifies a societal and scholarly neglect for the field of small business ownership and health. We address health capital and its spillover effects and briefly outline a research program discriminating between pathogenic (negative for health) and salutogenic (positive for health) effects for a small business owner's working life.
\end{abstract}

Keywords Small business owners · Entrepreneurship · Health $\cdot$ Well-being $\cdot$ Salutogenesis

JEL classification $\mathrm{I} 30 \cdot \mathrm{L} 26$

O. Torrès

University of Montpellier, MRM, Montpellier, France

e-mail: olivier.torres@univ-montp3.fr

O. Torrès $\cdot$ R. Thurik

Montpellier Business School (Labex Entreprendre), 2300 Avenue des Moulins, 34185 Montpellier, France

R. Thurik $(\bowtie)$

Department of Applied Economics, Erasmus School of Economics, Erasmus University Rotterdam, Rotterdam, The Netherlands

e-mail: thurik@ese.eur.nl

R. Thurik

Erasmus University Rotterdam Institute for Behavior and Biology, Erasmus University Rotterdam, Rotterdam, The Netherlands

\section{The health of small business owners}

Despite the societal and economic significance of small businesses, the study of the health of their owners has been largely neglected. A small research institute AMAROK was established 10 years ago to analyze precisely this. It is closely connected to the University of Montpellier and the Montpellier Business School. It is not just involved with collecting health data of entrepreneurs but also with studying them for scientific and societal reasons. Moreover, there is a small assistance service connected to it to help out retailers with psychologic support in case of a shop robbery. The scientific analysis and its dissemination are done within a large network of colleagues and friends in France and abroad. In this respect, the first international workshop Health of Small Business Owners and Entrepreneurs held at the Montpellier Business School on September 2930, 2016, was a milestone.

The present article provides a cursory introduction into the field of small business owners and health. For wider and more systematic overviews, we refer to Torrès (2012a) and Stephan (2018), respectively. The present section deals with health capital and its spillover effects. The second section provides some reflections on why it took so long for applied and scholarly researchers to discover the field. The third section provides some ideas about what a research program may look like and the fourth one concludes stressing the virtues of the discrimination between not just a pathogenic side of business ownership but also a salutogenic one. 


\subsection{Health capital}

Steve Jobs was only 56 when he died in 2011. He was the emblem of Californian information technology in general and of Apple Computers in particular. His death hardly affected Apple Computers' share price. It could be argued that his death was horrible news but already expected because of his long period of illness, and that his death was "priced into" share value at the time that he died and that he was not the indisputable leader of Apple Computers any more. This, however, was precisely the case with Christophe de Margerie, president of the oil company Total, the biggest French company in terms of market capitalization. He died in an airplane crash in Moscow in 2014. Total share price hardly moved. The same is true for Carsten Schloter, director general of the biggest Swiss telephone company Swisscom, who committed suicide in 2013.

It may injure the pride of these captains of industry to know that their companies are too big to fail while they themselves are not. John-Kenneth Galbraith described the big international company as follows: "It is not to individuals but to organizations that power in the business enterprise and power in the society have passed. And modern economic society can only be understood as an effort, wholly successful, to synthesize by organization a group personality far superior for its purposes to a natural person, and with the added advantage of immortality" (Galbraith 1985, p. 74).

The impact of CEO morbidity and mortality is radically different for small firms. Henry Mintzberg put it as follows: "The Simple Structure is also the riskiest of structures, hinging on the health and whims of one individual. One heart attack can literally wipe out the organization's prime coordinating mechanism" (Mintzberg 1979, p. 312).

A longitudinal study of Becker and Hvide (2013) using data of 341 Norwegian small firms confirms this idea. It shows that following the owner's death, turnover drops in $60 \%$ of the cases and that employment drops in $17 \%$ of the cases. In even $20 \%$ of the cases, the firm goes bankrupt. The devastation effects of "death, divorce and disease" are often observed in the world of small businesses (Massey et al. 2004). By contrast, the symptoms and related personality traits of certain mental health conditions may be advantageous for entrepreneurs in some circumstances Freeman et al. (2018, this issue).
We arrive here at the main message of the present article and that of the special issue on Small Business Owners and Health. The health capital of the owner is the most important immaterial capital of a small firm (Torrès 2012a). The smaller the firm the bigger its vulnerability in case of a health problem of the owner, be it physical or mental.

\subsection{Spillover effects}

The health of the business owners may have spillover effects on their entourage, not just for the employed (Bono and Ilies 2006; Norman et al. 2005; Van Kleef 2009) but even for the family members because we know that life partners play a prime role when running a business (El Shoubaki et al. 2018). A Danish study shows "that there was a significant relation between entering entrepreneurship and receiving prescriptions for sedative/hypnotics both among the entrepreneurs themselves and their spouses, suggesting that entering entrepreneurship may be associated with increased stress for both the entrepreneurs and their families" (Dahl et al. 2010).

This spillover effect can even be established at an aggregate level. Blanchard et al. (2012) show a link between the number of independent small businesses and some health indicators such as mortality, occurrence of diabetes and obesity, in the surrounding area. The authors suggest that an entrepreneurial culture implies that people take destiny, including health issues, in their own hands. Clearly, more needs to be said about the causalities here. And also about the hypothesis that the spillover effects at the individual level may increase with decreasing size of the business: so-called proximity management (Torrès 2003; Julien 2007). Taken together, the direct and indirect spillover effects call for the careful analysis of small business owners' health.

\section{Why the health of small business owners is underresearched?}

Data on the health of small business owners are, until recently, hardly available and, consequently, there are only few studies attempting to explain health differences, their cause or their consequences. We focus on two reasons why this may be the case. 


\subsection{Focus on health of the employed}

Villermé (1840) was among the first to observe that the development towards mass industrialization led to pathogenic effects of a new and widespread nature among the workers. Occupational health care of the 19th and twentieth century had a social mission: to protect those who are most vulnerable like working children and women. The focus on the working class remained a central theme in health care legislation (Barthe 1944). And this focus, together with the advent of the managed economy with its dominance of the big enterprise (Audretsch and Thurik 2001), led to a certain disregard of health care arrangements of workers in small companies and their owners (Pinder et al. 2016; Hasle et al. 2009). The industry-wide arrangements of the late twentieth century brought the workers of the small companies alongside those in their bigger counterparts but the negligence of the owners remained intact.

The relatively low percentage of non-salary workers in developed countries of about $12 \%$ on average (OECD 2018) did not contribute to a catch-up mechanism, nor does their heterogeneity comprising of business owners with different legal backgrounds, self-employed, artisans, etc. This lacuna is sometimes described as follows: there appear to be more data and studies of the health of the blue whale than of entrepreneurs (Torrès 2012a). In view of the economic importance of small businesses in developed and developing economies, the health of small business owners is slowly becoming a public issue (Torrès 2012a; Vinberg et al. 2012; Stephan and Roesler 2010; Stephan 2018).

\subsection{Focus on the Schumpeterian hero}

The second reason for the neglect of the study of small business owners' health has to do with the romanticization of entrepreneurship and heroic entrepreneurs, which leaves no role for weaknesses, suffering, and, ultimately, health issues. Testimonies of small business owners about the adverse effects of their activities on their physical or mental health are rare. In a 2007 survey of the French Ministry of Labor, $58 \%$ of non-salaried workers said that they felt obliged to hide their emotions and to pretend being good humored whereas this percentage was $42 \%$ for salaried workers (Coutrot and Mermilliod 2010). A study of the French Public Investment Bank showing that the burnout risk for French small business owners is considerable earned very little recognition (Torrès and
Targy 2016). The optimistic Schumpetarian victorious warrior such as Richard Branson, Michael Dell, Andy Grove, and Bill Gates seems to be the obvious role model leaving no room for pathogenic perspectives.

Stress (Akande 1994; Lechat 2014; Cardon and Patel 2015; Hessels et al. 2017), work-family balance (Parasuraman et al. 1996; Kirkwood and Toothill 2008), work overload (Boyd and Gumpert 1983; Buttner 1992), and role conflicts (Parasuraman et al. 1996; INSERM 2011) are covered in the scholarly entrepreneurship literature but health, and bad health in particular, are only slowly making it into this literature. The present article with some focus on the pathogenic side is meant to compensate for this neglect.

\section{A research program addressing the health of small business owners}

Obviously, the link between small business owners and their health has two sides. How does ownership influence health and how does health influence ownership? The influence of health on ownership can have a selection effect (for instance, unhealthy people shy away from setting up a business) or a treatment effect (for instance, being an entrepreneur can be beneficial or detrimental for one's health). Or in the words of the present paper, the influence of ownership on health can be positive (salutogenesis) or detrimental (pathogenesis). Moreover, there can be confounding mechanisms: having lived as a child in an affluent, entrepreneurial family may have positive effects on both the likelihood of staying healthy and becoming an entrepreneur. Lastly, health can have both a mental and a physical dimension. We will attempt to deal with the above issues in the remainder of the present section.

\subsection{The causes of small business owners' health}

McMichael was the first to show that the mortality of workers is inferior to that of the general population (McMichael 1976). He attributed this to a selection effect: to get a job you need to be healthy. Of course, this selection process continues after a worker is recruited (Gollac and Volkoff 2006) which is termed the exclusion effect. The theory of the healthy worker effect has also been applied to small business owners (Chao et al. 2010; Rietveld et al. 2016; Baron et al. 2016; Gonçalves and Martins 2018). The attraction/selection/ 
attrition model of Schneider et al. (1995) is helpful to understand why certain people are attracted to certain employment environments, why certain employment environments select certain people and which combinations survive. Baron et al. (2016) apply this approach to small business ownership.

The process of selection and exclusion cannot be assumed to be similar for small business owners and employed persons. Small business owners take less sick leave than those working for them (Benavides et al. 2000; FSB 2006; Pfeifer 2013; Merchant et al. 2014). Pfeifer (2013) points at work satisfaction (based upon autonomy and identification) which plays a role here. Monneuse (2013) shows that working despite being ill is common among independent workers.

The distinction between "opportunity" and "necessity" applies to entrepreneurial entry and exit rather than to those of workers. The distinction between "opportunity entrepreneurship" and "necessity entrepreneurship" is a central theme in the work of the Global Entrepreneurship Monitor. Entrepreneurial entry by necessity may go together with the lower levels of mental sanity resulting from the previous state of unemployment. The same may be true for salaried workers. But the extent of these effects and the salutogenic effect of resuming work is still to be investigated.

A small but sympathetic literature is developing around micro businesses and handicapped persons who become self-employed by necessity (Callahan et al. 2002; Hagner and Davies 2002; Walls et al. 2001; Yamamoto et al. 2012) which contradicts the theory of the healthy worker effect. This is one more reason to develop a research program of the health of small business owners distinct from that of the employed. In some cases, less healthy persons may fit better in ownership roles than in wage work (Hessels et al. forthcoming).

All the above examples and small literatures show that the causes of the health of business owners and of workers may be different.

\subsection{The consequences for small business owners' health}

In her literature survey of types, antecedents, and consequences of the general mental well-being of entrepreneurs, Stephan (2018) discriminates between six broad categories: work characteristics (64 studies); personality traits; values and other personal resources (54 studies); firm and financial characteristics (37 studies); social support and stressors (25 studies); market and country context (26 studies); and physical context (four studies). She presents the antecedents according to whether they have positive effects (resources) or negative effects (stressors or vulnerabilities) on entrepreneurs' general mental well-being. We adopt a similar setup below (Torrès 2012a).

\subsubsection{The negative consequences of small business ownership for health}

Like any worker, small business owners are confronted with pathogenic factors, the most important being stress. Many studies such as Boyd and Gumpert (1983), Buttner (1992), Cardon and Patel (2015), Jamal (1997), and Andersson (2008) show that the owner faces higher stress levels than the employed. Mixed and nuanced results are shown in Algava et al. (2012), Prottas and Thompson (2006), and Oren (2012), while Rahim (1996) and Baron et al. (2016) identify owners with a lower stress level. Moreover, the discrimination between hindrance stressors (role conflict, role ambiguity, lack of resources, daily hassles, etc.) and challenge stressors (opportunities for personal learning, growth, responsibility, time pressure, achievement, etc.) (Rodell and Judge 2009; Cavanaugh et al. 2000) will most likely provide some interesting results. Drawing upon the Job Demand-Control (JDC) model, Hessels et al. (2017) investigate differences in work-related stress between the self-employed and wage workers. Empirical analysis of a longitudinal Australian sample shows that the selfemployed experience less work-related stress than wage workers. What seems to be at play here is the role of Job control fully mediating the negative relationship between self-employment and work-related stress. In general, it cannot be assumed that the stress factors of owners and workers are similar (Grant and Ferris 2012; Lechat 2014; Lechat and Torrès 2017).

Work overload is another often studied pathogenic factor (Buttner 1992; Akande 1994; Ahmad and Salim 2009; Boyd and Gumpert 1983). Hahn et al. (2012) identify a weekly working time of nearly $58 \mathrm{~h}$ in a survey of 122 owner/managers of German small businesses. In a sample of 500 French small business owners, Torrès (2012b, p. 203) observes that two thirds work at least $50 \mathrm{~h}$ a week while sacrificing one weekend day. Working long hours, on diverse tasks or with high intensity, is not in itself a pathogenic factor. Research is 
definitively needed to establish how stress dimensions work out as pathogenic factors.

Uncertainty is often identified as an important pathogenic factor (Ferrie et al. 2005; Probst 2005). A Canadian study (INSERM 2011, p. 21.) identifies uncertainty, next to other factors such as long working hours, variation in turnover, and liquidity problems, as a major pathogenic influence. Also in France, uncertainty is documented to be a bigger problem for the selfemployed than for salaried workers (Coutrot and Mermilliod 2010). Finally, uncertainty and its pathogenic effects can easily spillover to the private life of family members (Westman et al. 2001).

Gumpert and Boyd (1984), however, focused on loneliness of business owners. It may contribute to the likelihood of burnout as a factor contributing again to lower experience of mental health (Jamal 2007; Shepherd et al. 2010; Ben Tahar 2014; Fernet et al. 2016). This loneliness can be particularly harmful when difficult decisions have to be taken such as firing employees (Torrès 2011).

The list of pathogenic candidates is nearly endless including role conflicts, work family balance issues, and financial problems (Stephan 2018).

\subsubsection{The theory of salutogenesis and sense of coherence}

Antonovsky $(1979,1987)$ was the first to show the beneficial effect of working life in a world where the negative effects such as mortality, morbidity, incapacity, and invalidity dominated. He used the terms salutogenesis and pathogenesis. "Formally, pathogenesis is the study of disease origins and causes. Pathogenesis starts by considering disease and infirmity and then works retrospectively to determine how individuals can avoid, manage, and/or eliminate that disease or infirmity. In contrast, salutogenesis, the study of health origins and causes, starts by considering health and looks prospectively at how to create, enhance, and improve physical, mental and social well-being" (Becker et al. 2010, p. 26). Antonovsky's views influenced the public health area which started to assimilate the promotion of good health next to the prevention of illnesses (Becker et al. 2002). Breed et al. (2006, p. 76) describe the functioning of salutogenesis as follows: "On the cognitive level, the individual is able to view stimuli from the environment in a positive and constructive manner, and to use the information towards effective decision making. On the affective level, the individual functions with self-awareness, confidence, self-fulfillment, viewing stimuli as meaningful and acting with commitment towards life in a mature manner. On the motivational level, the individual has intrinsic motivation, perceives stimuli as a challenge which directs his/her energy to cope, solve problems, and achieve results. The interpersonal characteristics entail the capacity to form meaningful and rewarding relationships with others at work and in society."

The romantic view of Filion (2011, p. 48) tells us much about salutogenesis for business owners: "An entrepreneur is an imaginative, intuitive, resourceful, tenacious actor, a results-oriented designer of innovations who is able to develop risky opportunities, who learns to be creative and resourceful, takes action by making practical use of limited resources and a network of contacts, and who is able to structure organizational activities to form a client satisfaction system that contributes an added value". We discover various aspects of salutogenesis in his text: motivation, care, analytical capacities, creativity, initiative, anticipation, foresight, ability to set goals and objectives, problem-solving skills, self-confidence related to clearly defined identity, long-term commitment, energy, result orientation, passion, (internal) locus-of-control, determination, perseverance, tenacity, resourcefulness, coordination, networking skills, flexibility, empathy, listening and communication skills, adaptability, ability to trust, seeks challenges (Filion 2011, p. 46).

And indeed, work satisfaction is recorded to be higher for business owners than for employed (Van der Zwan et al. 2018; Naughton 1987; Blanchflower and Oswald 2004; Benz and Frey 2004, 2008; Andersson 2008; Block and Koellinger 2009; Lange 2009; El Harbi and Grolleau 2012; Binder and Coad 2013, 2014; Kapoor 2001). The same is true for life satisfaction (Naughton 1987; Blanchflower and Oswald 1998; Kapoor 2001) although elsewhere some inconclusive results are found (Blanchflower and Oswald 2004; Block and Koellinger 2009; Andersson 2008).

A key element of salutogenesis is "sense of coherence" which Antonovksy developed on the basis of his account of World War II concentration camp survivors (Antonovsky 1979, 1987, 1993). Sense of coherence is defined by Antonovsky as follows: "a global orientation that expresses the extent to which one has a pervasive, enduring though dynamic feeling of confidence that (1) the stimuli deriving from one's 
internal and external environments in the course of living are structured, predictable and explicable; (2) the resources are available to one to meet the demands posed by these stimuli; and (3) these demands are challenges, worthy of investment and engagement." (Antonovsky 1987, p. 19). Eriksson and Lindström (2006) show in their vast literature survey that sense of coherence is strongly connected to perceived health, in particular, mental health. As far as we could find, there are only few studies for workers (Van Schalkwyk and Rothmann 2008; Muller and Rothmann 2009), for managers (Coetzee and Viviers 2006) or for small business owners (Debray et al. 2016).

\subsubsection{There is more to salutogenesis than sense of coherence}

Psychology research, and in particular positive psychology and health psychology, have studied other phenomena which have a positive effect on health, of which optimism is the most important one (Scheier and Carver 1987; Bruchon Schweitzer 2001; Carver and Scheier 2005; Mäkikangas and Kinnunen 2003; Rasmussen et al. 2009). Entrepreneurship research shows that business owners are generally more optimistic than the employed (Trevelyan 2008; Cossette 2014). Optimism is also identified as one of the components of psychological capital (Luthans et al. 2007) together with selfefficacy, hope, and resilience. The four components are considered as state phenomena rather than personality traits which suggests that they may change over time (Luthans 2012; De Hoe and Janssen 2016). Psychological capital slowly becomes an important object of entrepreneurship research (Hayek 2012; Baron et al. 2016; De Hoe and Janssen 2016). It has been measured at the level of business owners using several dimensions: optimism (Trevelyan 2008), hope (Jensen and Luthans 2002; Peterson and Luthans 2003), resilience (Bullough et al. 2014; Bernard and Dubard Barbosa 2016), and self-efficacy (Brandstatter 2011).

But the list of salutogenic factors is long. Strümpfer (1990) suggested that there are six significant salutogenic strengths: hardiness, internal locus of control, learned resourcefulness, potency, self-efficacy, and sense of coherence." Next to the factors of Strümpfer, Breed et al. (2006, p. 74) mention self-actualization, sense of coherence, hardiness, potency, self-efficacy, learned resourcefulness, internal locus of control, coping, well-being, creativity and flow, resilience, emotional intelligence, engagement, authenticity, happiness, humor, positive affect, courage, gratitude, faith, and optimism.

The most complete list of salutogenic factors is found in Lindström and Eriksson (2005) who discriminate between 25 ones.

Of course, there are caveats when studying salutogenesis. Binder and Coad (2014) show that salutogenesis plays a role for opportunity entrepreneurship but not for necessity entrepreneurship. Block and Koellinger (2009) identify a group of nascent entrepreneurs that cannot get satisfaction with their start-up because they did not choose to become entrepreneurs in the first place. This group of unsatisfied entrepreneurs includes individuals starting a business after a period of long-term unemployment and those individuals with a lack of better employment alternatives (necessity entrepreneurs). Van der Zwan et al. (2018) show that entrepreneurs show a higher level of work satisfaction but a lower life satisfaction. Fayolle (2013) and Fayolle and Nakara (2012) show that necessity entrepreneurship is the "hidden face of entrepreneurship" associated with job insecurity and precarious employment.

\section{Conclusion}

Apart from many other biologic and contextual factors, the health of small business owners depends upon the pathogenic and the salutogenic effects of their specific professional activities. Clearly, the same holds true for all other professions. The difference is that in the case of small business owners these effects may be more pronounced and that, given the societal and economic importance of small businesses, the type, the antecedents, and the consequences of both pathogenic and salutogenic effects are heavily underresearched (Torrès 2012a; Stephan 2018).

This calls for a big research agenda not just on the types, antecedents, and consequences of the many individual pathogenic and salutogenic effects but also on their interaction and impact on many aspects of the mental and physical health of small business owners. The remaining five articles of the present special issue will deal with several elements of such a research agenda. In particular, Freeman et al. (2018, this issue) look into the prevalence and co-occurrence of some psychiatric conditions among entrepreneurs in comparison with non-entrepreneurs. Toivanen et al. (2018, this 
issue) analyze differences in acute cardiovascular disease in terms of stroke and myocardial infarction incidence between self-employed individuals and paid employees using Swedish population survey data. Soenen et al. (2018, this issue) explore the impact of entrepreneurs' overall justice perceptions on emotional exhaustion and firm performance using the allostatic load model, developed in stress research. Canits et al. (2018, this issue) investigate the association between attention deficit hyperactivity disorder symptoms and academic entrepreneurial preference using data of French, Italian and Spanish university workers and the theoretical lens of Person-Environment fit. Lerner et al. (2018, this issue) aim to contribute by testing the connection between attention deficit hyperactivity disorder in the clinical sense and entrepreneurial intention and action based on a data set of nearly 10,000 students and cross-sectional methodology. Below, we will touch upon some other and miscellaneous aspects of such prospective research agenda.

There may be a temporal aspect in the balance between pathogenic and the salutogenic effects in that, for instance, the euphoric start of a new and growing venture gives way for the monotony of running an existing and sluggish business. The balance of pathogenic and salutogenic effects may change over time. There may even be feedback loops and dynamic effects. Ute Stephan explains this as follows: "This reinforces the need to pay greater attention to dynamic processes and changeability over time in understanding entrepreneur's work and their mental well-being. Future research should consider measures of variability and deviation of stressors and resources alongside mean scores" (Stephan 2018, p. 36).

The study of the physiology of the small business owner has not started yet in a coherent fashion: fatigue and sleep are probably crucial mediators between the many pathogenic and salutogenic effects and how they work out for mental and physical health. Is running a business tiresome, for whom and in what circumstances? Do entrepreneurial behaviors like being proactive, innovative and risk-taking influence the quality and quantity of sleep, and what kind of sleep? There is some early work of Florence Guiliani on sleep and its links to fatigue on entrepreneurial alertness (Guiliani 2016; Guiliani and Torrès 2017; Guiliani and Torrès forthcoming). In the same way, Gunia (forthcoming) explores the three-way relationship between sleep, mental health, and entrepreneurship, focusing on the important influence of sleep problems on entrepreneurial motives and means. Similarly, Baron (1998) deals with the link between fatigue and entrepreneurial cognition, in particular in environments with information overload, a high level of uncertainty or novelty and emotional and temporal pressures. Much remains to be learned about the physiology of the small business owner.

There is a lack of epidemiologic studies on phenomena like sick leave and time to return to work. Merchant et al. (2014) show that on average owner/managers of small businesses have less sick leave and shorter return times than employed workers. When one of the authors of the present article asked his surgeon about when he could resume working after a planned medical operation, the surgeon responded that it depended upon whether he was self-employed or not. Of course, this difference between non-salaried and salaried workers may be motivated by financial incentives or emotional reasons. There may even be confounding effects and common denominators such as resilience which increases the likelihood of establishing a business and lowers that of giving in to the suffering of illnesses. The epidemiologic results of Toivanen et al. (2018, this issue) on cardiovascular diseases tell us that business owners do not suffer from them more than salaried workers but that industry effects are at play.

There is definitively no need to invent new epidemiologic indicators and the comparison between small business owners and salaried workers can also reveal some of the beneficial effects of a salaried working life. Too often epidemiologic studies concentrate on the pathogenic effects of the working environment. The present special issue suffers from this same shortcoming because phenomena like attention deficit/hyperactivity disorder, self-reported psychiatric concerns, emotional exhaustion, stroke and myocardial infarction, and cardiovascular disease are investigated in the environment of small business owners or of those who aspire to become one. However, the many positive effects for small business owners when compared to their salaried counterparts may very well contribute to a future where epidemiologic studies consistently take salutogenic effects into account.

Acknowledgements The present article is the first of six articles of this special issue on Small Business Owners and Health. The articles are a selection of the papers presented at the first international workshop Health of Small Business Owners and Entrepreneurs held at the Montpellier Business School in France on 
September 29-30, 2016. This workshop was a joint effort of the Montpellier Business School, University of Montpellier, observatoire AMAROK, LABEX Entreprendre and EURIBEB (Erasmus University Rotterdam Institute of Behavior and Biology). A second international workshop was organized in collaboration with the fifteenth IECER (Interdisciplinary European Conference on Entrepreneurship Research) Conference in Siegen, Germany, September 20-22, 2017 in the form of a special track. The present article is based upon the introductory talks which Olivier Torrès and Roy Thurik gave at the 2016 Montpellier workshop. They would like to thank Indy Bernoster, Michael Freeman, Dan Lerner, and Niels Rietveld for comments on the present version. The present article was written in the honor of Thomas Lechat who sadly passed away in 2015 .

Open Access This article is distributed under the terms of the Creative Commons Attribution 4.0 International License (http:// creativecommons.org/licenses/by/4.0/), which permits unrestricted use, distribution, and reproduction in any medium, provided you give appropriate credit to the original author(s) and the source, provide a link to the Creative Commons license, and indicate if changes were made.

\section{References}

Ahmad, S. Z., \& Salim, F. A. A. (2009). Sources of stress and the coping mechanism for Malaysian entrepreneurs. African Journal of Business Management, 3(6), 311-316.

Akande, A. (1994). Coping with entrepreneurial stress: evidence from Nigeria. Journal of Small Business Management, 32(1), 83-87.

Algava, É., Cavalin, C., \& Célérier, S. (2012). La singulière bonne santé des indépendants. Travail et Emploi, 132, 5-20.

Andersson, P. (2008). Happiness and health: well-being among the self-employed. The Journal of Socio-Economics, 37(1), 213236.

Antonovsky, A. (1979). Health, stress and coping. San Francisco: The Jossey-Bass Social and Behavioural Science Series, first edition.

Antonovsky, A. (1987). Unraveling the mystery of health - how people manage stress and stay well. San Francisco: The Jossey-Bass Social and Behavioural Science Series, first edition.

Antonovsky, A. (1993). The structure and properties of the sense of coherence scale. Social Science \& Medicine, 36(6), 725733.

Audretsch, D. B., \& Thurik, A. R. (2001). What is new about the new economy: sources of growth in the managed and entrepreneurial economies. Industrial and Corporate Change, 10(1), 267-315.

Baron, R. A. (1998). Cognitive mechanisms in entrepreneurship: why and when entrepreneurs think differently than other people. Journal of Business Venturing, 13(4), 275-294.

Baron, R. A., Franklin, R. J., \& Hmieleski, K. M. (2016). Why entrepreneurs often experience low, not high, levels of stress: the joint effects of selection and psychological capital. Journal of Management, 42(3), 742-768.
Barthe, R. (1944). La médecine du travail. Paris: Presses Universitaires de France.

Becker, S. O., \& Hvide, H. K. (2013). Do entrepreneurs matter? Discussion Paper Series, IZA Forschungsinstitut zur Zukunft der Arbeit, No. 7146. http://hdl.handle.net/10419/69337.

Becker, C. M., McMahan, S., Etnier, J., \& Nelson, J. R. (2002). The potency of health promotion versus disease prevention messages in a college population. American Journal of Health Studies, 18(1), 26-30.

Becker, C. M., Glascoff, M. A., \& Felts, W. M. (2010). Salutogenesis 30 years later: where do we go from here? The International Electronic Journal of Health Education, 13, 25-32.

Ben Tahar, Y. (2014). Analyse du burnout en entrepreneuriat: une étude empirique sur les dirigeants de PME. Phd thesis, University of Montpellier I, France. https://tel.archivesouvertes.fr/tel-01202577/document.

Benavides, F. G., Benach, J., Diez-Roux, A. V., \& Roman, C. (2000). How do types of employment relate to health indicators? Findings from the second European survey on working conditions. Journal of Epidemiology and Community Health, 54(7), 644-501.

Benz, M., \& Frey, B. S. (2004). Being independent raises happiness at work. Swedish Economic Policy Review, 11(2), 95134.

Benz, M., \& Frey, B. S. (2008). Being independent is a great thing: subjective evaluations of self-employment and hierarchy. Economica, 75(298), 362-383.

Bernard, M. J., \& Dubard Barbosa, S. (2016). Resilience and entrepreneurship: a dynamic and biographical approach to the entrepreneurial act. $M @ n @ g e m e n t, 19(2), 89-123$.

Binder, M., \& Coad, A. (2013). Life satisfaction and self-employment: a matching approach. Small Business Economics, 40(4), 1009-1033.

Binder, M., \& Coad, A. (2014). How satisfied are the selfemployed? A life domain view. SPRU Working Paper Series. https://econpapers.repec.org/RePEc:sru:ssewps:201417.

Blanchard, T. C., Tolbert, C., \& Mencken, C. (2012). The health and wealth of US counties: how the small business environment impacts alternative measures of development. Cambridge Journal of Regions, Economy and Society, 5(1), 164-162.

Blanchflower, D. G., \& Oswald, A. (1998). What makes an entrepreneur? Journal of Labor Economics, 16(1), 26-60.

Blanchflower, D. G., \& Oswald, A. (2004). Well-being over time in Britain and the USA. Journal of Public Economics, 88(78), 1359-1386.

Block, J. H., \& Koellinger, P. (2009). I can't get no satisfactionnecessity entrepreneurship and procedural utility. Kyklos, 62(2), 191-209.

Bono, J. E., \& Ilies, R. (2006). Charisma, positive emotions and mood contagion. The Leadership Quarterly, 17(4), 317-334.

Boyd, D. P., \& Gumpert, D. E. (1983). Coping with entrepreneurial stress. Harvard Business Review, March/April, pp 44-64.

Brandstatter, H. (2011). Personality aspects of entrepreneurship: a look at five meta-analyses. Personality and Individual Differences, 51(3), 222-230.

Breed, M., Cilliers, F., \& Visser, D. (2006). The factor structure of six salutogenic constructs. The Journal of Individual Psychology, 32(1), 74-87. 
Bruchon Schweitzer, M. (2001). Concepts, stress, coping. Recherche en Soins Infirmiers, 67, 4-39.

Bullough, A., Renko, M., \& Myatt, T. (2014). Danger zone entrepreneurs: the importance of resilience and self-efficacy for entrepreneurial intentions. Entrepreneurship Theory and Practice, 38(3), 473-649.

Buttner, H. E. (1992). Entrepreneurial stress: is it hazardous to your health? Journal of Managerial Issues, 4(2), 223-240.

Callahan, M., Shumpert, N., \& Mast, M. (2002). Self-employment, choice and self-determination. Journal of Vocational Rehabilitation, 17(2), 75-85.

Canits, I., Bernoster, I., Mukerjee, J., Bonnet, J., Rizzo, U., \& Rosique-Blasco, M. (2018). Attention-deficit/hyperactivity disorder (ADHD) symptoms and academic entrepreneurial preference: is there an association? Small Business Economics, this issue.

Cardon, M. S., \& Patel, P. C. (2015). Is stress worth it? Stressrelated health and wealth trade-offs for entrepreneurs. Applied Psychology, 64(2), 379-420.

Carver, C. S., \& Scheier, M. F. (2005). Optimism. In C. R. Snyder \& S. J. Lopez (Eds.), Handbook of positive psychology (pp. 231-256). Oxford: University Press.

Cavanaugh, M. A., Boswell, W. R., Roehling, M. V., \& Boudreau, J. W. (2000). An empirical examination of self-reported work stress among U.S. managers. Journal of Applied Psychology, 85(1), 65-74.

Chao, L. W., Szrek, H., Sousa Pereira, N., \& Pauly, M. V. (2010). Too sick to start: entrepreneur's health and business entry in townships around Durban, South Africa. Journal of Developmental Entrepreneurship, 15(2), 231-242.

Coetzee, M. G., \& Viviers, A. M. (2006). Managerial level, managerial motivation and sense of coherence. The Journal of Individual Psychology, 33(3), 35-42.

Cossette, P. (2014). Heuristics and cognitive biases in entrepreneurs: a review of the research. Journal of Small Business \& Entrepreneurship, 27(5), 471-496.

Coutrot, T., \& Mermilliod, C. (2010). Les risques psychosociaux au travail: les indicateurs disponibles. DARES Analyses, 081. Paris: Direction de l'animation de la recherche, des études et des statistiques (Dares).

Dahl, M. S., Nielsen, J., \& Mojtabai, R. (2010). The effects of becoming an entrepreneur on the use of psychotropics among entrepreneurs and their spouses. Scandinavian Journal of Public Health, 38(8), 857-863.

De Hoe, R., \& Janssen, F. (2016). Le capital psychologique permet-il d'apprendre et de rebondir face à un échec entrepreneurial? Management International, 20(2), 18-28.

Debray, C., Paradas, A., Fournier, C., \& Torrès, O. (2016). The relationship between the sense of coherence in the directors of SMEs, and their perception of stress, isolation, and physical and mental health. $32^{\text {nd }}$ EGOS Colloquium, July 7-9, Naples, Italy.

El Harbi, S., \& Grolleau, G. (2012). Does self-employment contribute to national happiness? The Journal of SocioEconomics, 41(5), 670-676.

El Shoubaki, A., Block, J., Lasch, F. (2018). Life-partners and business partners: a review of a unique form of family business. Mimeo.

Eriksson, M., \& Lindström, B. (2006). Antonovsky's sense of coherence. Scale and the relation with health: a systematic review. Journal of Epidemiology and Community Health, 60(5), 376-381.

Fayolle, A. (2013). Necessity entrepreneurship and job insecurity: the hidden face of entrepreneurship. International Journal of Entrepreneurship and Innovation, 2(3), 1-10.

Fayolle, A., \& Nakara, W. (2012). Création par nécessité et précarité: la face cachée de l'entrepreneuriat. Economies et Societes, 46(9), 1729-1764.

Federation of Small Businesses. (2006). Health matters: the small business perspective. FSB Survey Report 2006.

Fernet, C., Torrès, O., Austin, S., \& St Pierre, J. (2016). The psychological costs of owning and managing an SME: linking job stressors, occupational loneliness, entrepreneurial orientation and burnout. Burnout Research, 3(2), 45-53.

Ferrie, J. E., Shipley, M. J., Newman, K., Stansfeld, S. A., \& Marmot, M. (2005). Self-reported job insecurity and health in the Whitehall II study: potential explanations of the relationship. Social Science \& Medicine, 60(7), 1593-1602.

Filion, L. J. (2011). Defining the entrepreneur. In L. P. Dana (Ed.), World encyclopedia of entrepreneurship (pp. 41-42). Cheltenham and Northampton: Edward Elgar.

Freeman, M. A., Staudenmaier, P. J., Zisser, M. R., \& Abdilova Andresen, L. (2018). The prevalence and co-occurrence of psychiatric conditions among entrepreneurs and their families. Small Business Economics, this issue.

Galbraith, J. K. (1985). The new industrial state (4th ed.). Princeton: Princeton University Press.

Gollac, M., \& Volkoff, S. (2006). La santé au travail et ses masques. Actes de la recherche en sciences sociales, 3(163), 4-17.

Gonçalves, J., \& Martins, P. S. (2018). The effect of selfemployment on health: evidence from longitudinal social security data. IZA Discussion Papers Series, 11305. RePEc: iza:izadps:dp11305.

Grant, S., \& Ferris, K. (2012). Identifying sources of occupational stress in entrepreneurs for measurement. International Journal of Entrepreneurial Venturing, 4(4), 351-373.

Guiliani, F. (2016). La vigilance entrepreneuriale: les antécédents liés au sommeil du dirigeant de PME. Phd thesis, University of Montpellier, France.

Guiliani, F., \& Torrès, O. (2017). L'influence de la somnolence et de la concentration sur la vigilance entrepreneuriale des dirigeants de PME. Revue de l'Entrepreneuriat, 16(3-4), 137-166.

Guiliani, F., \& Torrès, O. (forthcoming). entrepreneurship: an insomniac discipline? An empirical study on SME owners/ directors. International Journal of Entrepreneurship and Small Business.

Gumpert, D. E., \& Boyd, D. P. (1984). The loneliness of the smallbusiness owner. Harvard Business Review, NovemberDecember, 18-24.

Gunia, B. C. (forthcoming). The sleep trap: do sleep problems prompt entrepreneurial motives but undermine entrepreneurial means? Academy of Management Perspectives. https://doi.org/10.5465/amp.2016.0159.

Hagner, D., \& Davies, T. (2002). "Doing my own thing": supported self-employment for individuals with cognitive disabilities. Journal of Vocational Rehabilitation, 17(2), 65-74.

Hahn, V. C., Frese, M., Binnewies, C., \& Schmitt, A. (2012). Happy and proactive? The role of hedonic and eudaimonic 
well-being in business owners' personal initiative. Entrepreneurship Theory and Practice, 36(1), 97-114.

Hasle, P., Kines, P., \& Andersen, L. P. (2009). Small enterprise owners' accident causation attribution and prevention. Safety Science, 47(1), 9-19.

Hayek, M. (2012). Control beliefs and positive psychological capital. Can nascent entrepreneurs discriminate between what can and cannot controlled? Journal of Management Research, 12(1), 3-13.

Hessels, J., Rietveld, C. A., \& Van der Zwan, P. (2017). Selfemployment and work-related stress: the mediating role of job control and job demand. Journal of Business Venturing, 32(2), 178-196.

Hessels, J., Rietveld, C. A., Thurik, A. R., \& Van der Zwan, P. (forthcoming). Mental health and entrepreneurial exit. Academy of Management Perspectives.

INSERM. (2011). Stress au travail et santé: Situation chez les indépendants. Paris: EDP sciences.

Jamal, M. (1997). Job stress, satisfaction, and mental health: an empirical examination of self-employed and non-selfemployed Canadians. Journal of Small Business Management, 35(4), 48-57.

Jamal, M. (2007). Burnout and self-employment: a cross-cultural empirical study. Stress and Health, 23(4), 264-256.

Jensen, S. M., \& Luthans, F. (2002). The impact of hope in the entrepreneurial process. Decision Sciences Institute Annual Meeting Proceedings, \#OB-287, 1696-1701.

Julien, P. A. (2007). A theory of local entrepreneurship in the knowledge economy. Northampton: Edward Elgar.

Kapoor, S. (2001). Job satisfaction: a comparative analysis of franchisees and small business owners in Australia and the validation of a model. Thesis, University of South Australia, Adelaïde.

Kirkwood, J., \& Toothill, B. (2008). Is entrepreneurship the answer to achieving work-family balance? Journal of Management and Organization, 14(3), 285-302.

Lange, T. (2009). Job satisfaction and self-employment: autonomy or personality? Small Business Economics, 38(2), 165-177.

Lechat, T. (2014). Les évènements stressants et satisfaisants de l'activité entrepreneuriale et leur impact sur la santé du dirigeant de PME. Phd thesis, University of Montpellier, France.

Lechat, T., \& Torrès, O. (2017). Stressors and satisfactors in entrepreneurial activity: an event-based, mixed methods study predicting small business owners' health. International Journal of Entrepreneurship and Small Business, 32(4), 537-569.

Lerner, D. A., Verheul, I., \& Thurik, A. R. (2018). Entrepreneurship and attention deficit/hyperactivity disorder: a large-scale study involving the clinical condition of ADHD. Small Business Economics, this issue.

Lindström, B., \& Eriksson, M. (2005). Salutogenesis. Journal of Epidemiology and Community Health, 59(6), 440-442.

Luthans, F. (2012). Psychological capital: implications for HRD, retrospective analysis, and future directions. Human Resource Development Quarterly, 23(1), 1-8.

Luthans, F., Avolio, B. J., Avey, J. B., \& Norman, S. M. (2007). Positive psychological capital: measurement and relationship with performance and satisfaction. Personnel Psychology, 60(3), 541-572.
Mäkikangas, A., \& Kinnunen, U. (2003). Psychosocial work stressors and well-being: self-esteem and optimism as moderators in a one-year longitudinal sample. Personality and Individual Differences, 35(3), 537-557.

Massey, C., Harris, C., \& Lewis, K. (2004). Death, divorce and disease: personal life event and the business life-cycle. European Council for Small Business, RENT XVIII Conference, Copenhagen, November.

McMichael, A. J. (1976). Standardized mortality ratios and the "healthy worker effect": scratching beneath the surface. Journal of Occupational Medicine, 18(3), 165-168.

Merchant, J. A., Kelly, K. M., Burmeister, L. F., Lozier, M. J., Amendola, A., Lind, D. P., KcKeen, A., Slater, T., Hall, J. L., Rohlman, D. S., \& Buikema, B. S. (2014). Employment status matters: a statewide survey of quality-of-life, prevention behaviors, and absenteeism and presenteeism. Journal of Occupational and Environmental Medicine, 56(7), 686-698.

Mintzberg, H. (1979). The structuring of organizations. Englewood Cliffs, NJ: Prentice-Hall.

Monneuse, D. (2013). Le surprésentéisme - Travailler malgré la maladie. Brussels: Editions De Boeck.

Muller, Y., \& Rothmann, S. (2009). Sense of coherence and employees' perceptions of helping and restraining factors in an organisation. South African Journal of Industrial Psychology, 35(1), 1-10.

Naughton, T. J. (1987). Quality of working life and the selfemployed manager. American Journal of Small Business, 12(2), 33-40.

Norman, S., Luthans, B., \& Luthans, K. (2005). The proposed contagion effect of hopeful leaders on the resiliency of employees and organizations. Journal of Leadership \& Organizational Studies, 12(2), 55-64.

OECD. (2018). Self-employment rate (indicator). https://doi. org $/ 10.1787 / \mathrm{fb} 58715 \mathrm{e}-\mathrm{en}$.

Oren, L. (2012). Job stress and coping: self-employed versus organizationally employed professionals. Stress and Health, 28(2), 163-170.

Parasuraman, S., Purohit, Y. S., Godshalk, V. M., \& Beutell, N. J. (1996). Work and family variables, entrepreneurial career success and psychological well-being. Journal of Vocational Behavior, 48(3), 275-300.

Peterson, S., \& Luthans, F. (2003). The positive impact and development of hopeful leaders. Leadership and Organization Development Journal, 24(1), 26-31.

Pfeifer, C. (2013). Cyclical absenteeism among private sector, public sector and self-employed workers. Health Economics, 22(3), 366-370.

Pinder, J., Gibb, A., Dainty, A., Jones, W., Fray, M., Hartley, R., Cheyne, A., Finneran, A., Glover, J., Haslam, R., \& Morgan, J. (2016). Occupational safety and health and smaller organisations: research challenges and opportunities. Policy and Practice in Health and Safety, 14(1), 34-64.

Probst, T. M. (2005). Economic stressors. In J. Barling, E. K. Kelloway, \& M. R. Frone (Eds.), Handbook of work stress (pp. 267-298). Thousand Oaks: Sage Publications.

Prottas, D. J., \& Thompson, C. A. (2006). Stress, satisfaction, and the work-family interface: A comparison of self-employed business owners, independents, and organizational employees. Journal of Occupational Health Psychology, 11(4), 366-378. 
Rahim, A. (1996). Stress, strain, and their moderators: an empirical comparison of entrepreneurs and managers. Journal of Small Business Management, 34(1), 46-58.

Rasmussen, H. N., Scheier, M. F., \& Greenhouse, J. B. (2009). Optimism and physical health: a meta-analytic review. Annals of Behavioral Medicine, 37(3), 239-256.

Rietveld, C. A., Bailey, H., Hessels, J., \& van der Zwan, P. (2016). Health and entrepreneurship in four Caribbean Basin countries. Economics and Human Biology, 21, 84-89.

Rodell, J. B., \& Judge, T. A. (2009). Can good stressors spark bad behavior? The mediating role of emotions in links of challenge and hindrance stressors with citizenship and counterproductive behaviors. Journal of Applied Psychology, 94(6), 1438-1451.

Scheier, M. F., \& Carver, C. S. (1987). Dispositional optimism and physical well-being. The influence of generalized outcome expectancies on health. Journal of Personality, 55(2), 169210 .

Schneider, B., Goldstein, H. W., \& Smith, D. B. (1995). The ASA framework: an update. Personnel Psychology, 48(4), 747773.

Shepherd, C. D., Marchisio, G., Morrish, S. C., Deacon, J. H., \& Miles, M. P. (2010). Entrepreneurial burnout: exploring antecedents, dimensions and outcome. Journal of Research in Marketing and Entrepreneurship, 12(1), 71-79.

Soenen, G., Eib, C., \& Torrès, O. (2018). The cost of injustice: overall justice, emotional exhaustion, and performance among entrepreneurs: do founders fare better? Small Business Economics, this issue.

Stephan, U. (2018). Entrepreneurs' mental health and well-being: a review and research agenda. Academy of Management Perspectives. https://doi.org/10.5465/amp.2017.0001.

Stephan, U., \& Roesler, U. (2010). Health of entrepreneurs versus employees in a national representative sample. Journal of Occupational \& Organizational Psychology, 83(3), 717738.

Strümpfer, D. J. W. (1990). Salutogenesis: a new paradigm. South Africa Journal of Psychology, 20(4), 264-276.

Toivanen, S., Härter Griep, R., Mellner, Ch., Nordenmark, M., Vinberg, S., \& Eloranta, S. (2018). Hospitalization due to stroke and myocardial infarction in self-employed individuals and small business owners compared with paid employees in Sweden - a five-year study. Small Business Economics, this issue.

Torrès, O. (2003). Petitesse des entreprises et grossissement des effets de proximité. Revue Française de Gestion, 144, 119138.
Torrès, O. (2011). The silent and shameful suffering of bosses: layoffs in SME. International Journal of Entrepreneurship \& Small Business, 13(2), 181-192.

Torrès, O. (2012a). La santé du dirigeant - de la souffrance patronale à l'entrepreneuriat salutaire. Brussels: Editions De Boeck.

Torrès, O. (2012b). Premiers résultats d'une étude épidémiologique sur la santé des dirigeants de PME. In O. Torrès (Ed.), La santé du dirigeant - de la souffrance patronale à l'entrepreneuriat salutaire (pp. 191-209). Brussels: Editions De Boeck.

Torrès, O., \& Targy, D. (2016). Vaincre les solitudes du dirigeant. Paris: BPI France Le LAB.

Trevelyan, R. (2008). Optimism, overconfidence and entrepreneurial activity. Management Decision, 46(7), 986-1001.

Van der Zwan, P., Hessels, J., \& Rietveld, C. A. (2018). Selfemployment and satisfaction with life, work, and leisure. Journal of Economic Psychology, 64, 73-88.

Van Kleef, G. A. (2009). How emotions regulate social life: the emotions as social information (EASI) model. Current Directions in Psychological Science, 18, 184-188.

Van Schalkwyk, L., \& Rothmann, S. (2008). Validation of the orientation to life questionnaire (OLQ) in a chemical factory. The Journal of Individual Psychology, 34(2), 31-39.

Villermé, L. R. (1840). Tableau de l'état physique et moral des ouvriers employés dans les manufactures de coton, de laine et de soie. Republished by Chaline, J. P., \& Démier, F. Paris: EDI, 1989.

Vinberg, S., Gundersen, K. T., Nordenmark, M., Larsson, J., \& Landstad, B. J. (2012). Entrepreneurs' health - the importance of psychosocial working conditions and individual factors. International Journal of Entrepreneurial Venturing, 4(4), 374-390.

Walls, R. T., Dowler, D. L., Cordingly, K., Orslene, L. E., \& Greer, J. D. (2001). Micro enterprising and people with disabilities: strategies for success and failure. Journal of Rehabilitation, 67(2), 29-35.

Westman, M., Etzion, D., \& Danon, E. (2001). Job insecurity and crossover of burnout in married couples. Journal of Organizational Behavior, 22(5), 467-481.

Yamamoto, S., Unruh, D., \& Bullis, M. (2012). The viability of self-employment for individuals with disabilities in the United States: a synthesis of the empirical-research literature. Journal of Vocational Rehabilitation, 36(2), 121-134. 